\title{
Impact of the Eastern Weddell Ice Shelves on water masses in the eastern Weddell Sea
}

\author{
Malte Thoma, ${ }^{1,2}$ KlausGrosfeld, ${ }^{3,4}$ and Manfred A. Lange ${ }^{1}$ \\ Received 9 August 2005; revised 2 June 2006; accepted 14 August 2006; published 12 December 2006.
}

[1] We use a primitive equation Ocean General Circulation Model to simulate the ocean circulation regime in the Eastern Weddell Sea. The computer model ROMBAX (Revisited Ocean Model based on Bryan And Cox) is an improved version of an earlier ocean model, which has been developed to allow the simulation of the flow regime in ice shelf covered regions. The Eastern Weddell Ice Shelf (EWIS) region is of particular importance because of its narrow continental shelf and its location at the inflow of water masses from the east into the southern Weddell Sea. We have compared the simulated flow pattern and water properties in the EWIS region with the available sparse observations. While the general observed structure of temperature and salinity is reproduced, the model tends to overestimate the on-shore flow of warm deep waters. This discrepancy is not large enough to seriously influence the ice shelf ocean interaction, which is in good agreement with estimates based on field observations. The mean net melt rate is found to be $0.88 \mathrm{~m} \mathrm{yr}^{-1}(2.1 \mathrm{mSv})$ and has a strong seasonal cycle. Sensitivity studies with different ice shelf configurations (no melting, no ice shelf, closed cavity) show strong impacts on the water mass properties in the EWIS region, with up to $0.7^{\circ} \mathrm{C}$ difference in temperature and 0.05 in salinity relative to the control run. Our results suggest that the EWIS region is of substantial importance to water mass preconditioning and formation in the Weddell Sea, although no deep or bottom water formation occurs in the eastern Weddell Sea directly.

Citation: Thoma, M., K. Grosfeld, and M. A. Lange (2006), Impact of the Eastern Weddell Ice Shelves on water masses in the eastern Weddell Sea, J. Geophys. Res., 111, C12010, doi:10.1029/2005JC003212.

\section{Introduction}

[2] The interface between the Antarctic Ice Sheet and the Southern Ocean comprises the base of the floating ice shelves that fringe about one half of Antarctica's coastline [Fox and Cooper, 1994]. Heat and mass fluxes associated with melting and freezing processes at this interface, directly affect the ice shelf system. Furthermore, the modification of saline shelf waters which results from this melting and freezing is closely linked with the formation of deep and bottom waters [Weiss et al., 1979; Foldvik and Gammelsrød, 1988]. Hence, the export of Ice Shelf Water (ISW) from the extensive ice shelf cavities, especially in the Weddell and Ross Seas, represents an important component in the ventilation of the world ocean abyss. In addition to the major ice shelf regions, the smaller ice shelves in the Weddell Sea, such as the Larsen Ice Shelf (LIS) in the west and the Eastern Weddell Ice Shelves (EWIS), may also be

\footnotetext{
${ }^{1}$ Institute for Geophysics, University of Münster, Münster, Germany.

${ }^{2}$ Now at British Antarctic Survey, Cambridge, UK.

${ }^{3}$ Department of Physics/MARUM, University of Bremen, Bremen, Germany.

${ }^{4}$ Now at Alfred Wegener Institute for Polar and Marine Research, Bremerhaven, Germany.
}

Copyright 2006 by the American Geophysical Union. 0148-0227/06/2005JC003212\$09.00 important contributors to the freshwater budget and hence to the preconditioning of Weddell Sea continental shelf water masses. The size of their contribution, however, is still under discussion and not yet determined.

[3] A map of the Weddell Sea, its adjacent ocean basins and ice shelf regions is given in Figure 1a. The eastwardflowing Antarctic Circumpolar Current (ACC) surrounds the Antarctic continent between $40^{\circ}$ and $60^{\circ}$ South and connects the Atlantic, Indian, and Pacific Ocean basins. Frontal systems associated with the ACC separate the subtropical ocean from the Antarctic continent. The Weddell Gyre interacts at its northern rim with the ACC and forms part of the westward-flowing Antarctic Coastal Current at its southern rim (Figure 1a). The interaction between the waters over the Weddell continental shelf and the three major Weddell sector ice shelves, the EWIS in the east, the Filchner Ronne Ice Shelf (FRIS) in the south, and LIS in the west, yields an important contribution to deep and bottom water formation as a result of the production of very cold water fraction, ISW [Foldvik et al., 1985].

[4] In this study we concentrate on the eastern Weddell Sea sector. No deep or bottom waters are formed in this region because the necessary shelf water salinity is not attained [Fahrbach et al., 1994a; Baines and Condie, 1998].

[5] The EWIS region is of special interest as it is separated from the Antarctic Coastal Current by only a narrow and steep continental shelf margin (Figure 2), hence, 

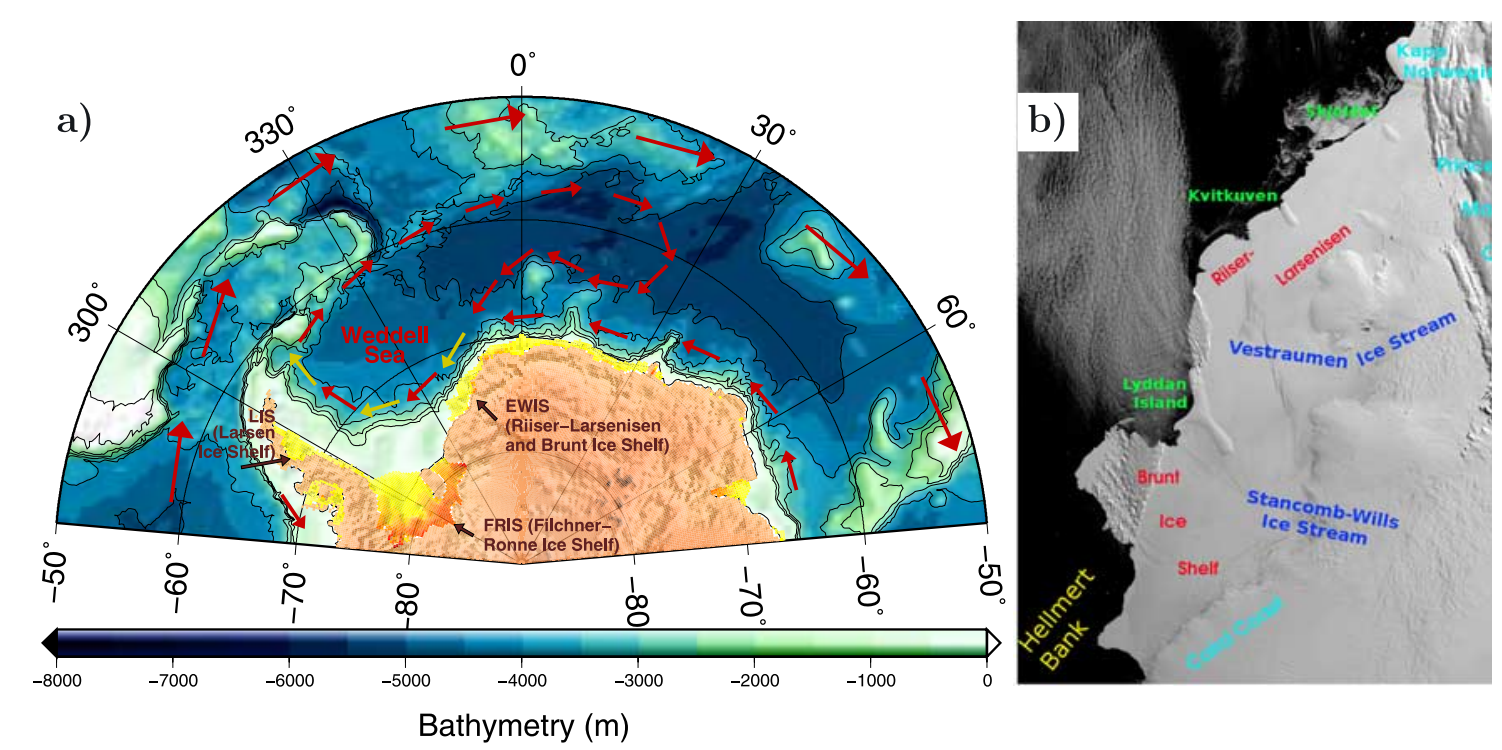

Figure 1. (a) Main ocean currents in the Weddell Sea and the adjacent ocean basins. Long red arrows indicate the ACC, short red arrows the Weddell Gyre and to the south the Antarctic Coastal Current, and yellow arrows indicate the admixture of Ice Shelf Water. Ice shelves are marked in yellow (merging into red with thickening) and inland ice in copper (data from Lythe et al. [2001]). (b) Satellite image from February 19, 2003, of EWIS, National Snow and Ice Data Center (NSIDC).

direct interaction between the coastal current and the ice shelf cavity is expected. This might be the cause of the observed high melt rates [Fahrbach et al., 1994a] and to modifications of the coastal current [Nicolaus and Grosfeld, 2002]. Recent modelling studies [Timmermann and Beckmann, 2004; Hellmer, 2004] also indicate substantial melt rates underneath the ice shelves in this region. In contrast, the extensive Filchner-Ronne continental shelf has a distinct flow regime that separates the seaward branch of the Antarctic coastal current from the FRIS, located about $400 \mathrm{~km}$ to the south [Grosfeld and Gerdes, 1998; Timmermann et al., 2002b; Jenkins and Holland, 2002]. Beckmann and Goosse [2003] discriminate between "type 1" and "type 2" ice shelves, respectively. Type 1 represents comparatively large ice shelves with broad continental shelf regions separating ice front and shelf break (e.g., FRIS, Ross Ice Shelf). Type 2 ice shelves are comparatively small in size and located close to the continental shelf break (e.g., Ekström Ice Shelf, Fimbulisen, EWIS). These ice shelves experience increased oceanic heat fluxes as a result of their proximity to the relatively warm coastal current. Nicolaus and Grosfeld [2002] demonstrate the importance of spatial respesentation of the continental shelf in modelling ice shelf - ocean interactions, particularly melt processes, in regions of type 2 ice shelves. They found a $30 \%$ reduction in the basal melt rate with an increase of the continental shelf width from $35 \mathrm{~km}$ to $46 \mathrm{~km}$ in front of Ekström Ice Shelf. To resolve the continental shelf in front of the EWIS (shelf width between $0 \mathrm{~km}$ and about $70 \mathrm{~km}$ ) and to enable an acceptable resolution of shelf processes, we use a ocean model resolution of $10 \mathrm{~km}$ in our efforts to estimate the freshwater production rate and analyse the influence of the ice shelf region on the water masses in the south-eastern Weddell Sea.

[6] The EWIS region includes the Riiser-Larsenisen in the north and Brunt Ice Shelf in the south (Figure 1b), separated by Lyddan Island, and covers a total area of $7.5 \times 10^{4} \mathrm{~km}^{2}$ in the model. Two additional ice rumples near the ice front of Riiser-Larsenisen, Skjoldet and Kvitkuven, act as anchor points for the ice shelf flow. Brunt Ice Shelf is mainly fed by discharge from Stancomb-Wills Ice Stream, while the major ice stream draining into Riiser-Larsenisen is Veststraumen Ice Stream. Ice thicknesses of up to $600 \mathrm{~m}$ are found, where the ice streams from the hinterland enter the EWIS region.

[7] This paper is organised as follows. The model is introduced in section 2. Analyses of the flow pattern, the water properties, and the freshwater production in the EWIS region are presented in section 3 . In addition, model runs for

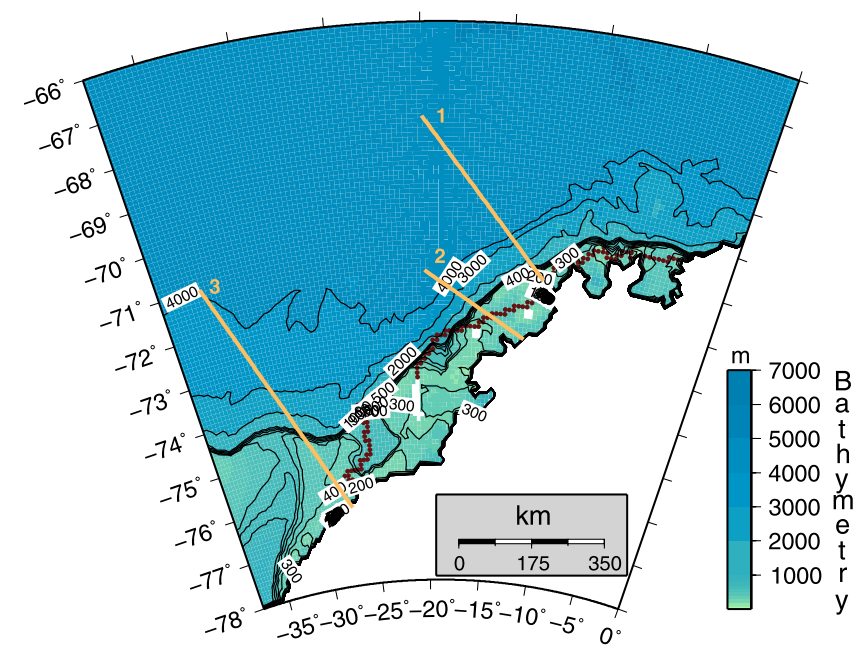

Figure 2. Bathymetry of the Eastern Weddell Sea and its adjacent ice shelf cavities after Lythe et al. [2001]. Logarithmic color scale aims to emphasize shallow regions. Straight lines indicate profile track positions. 


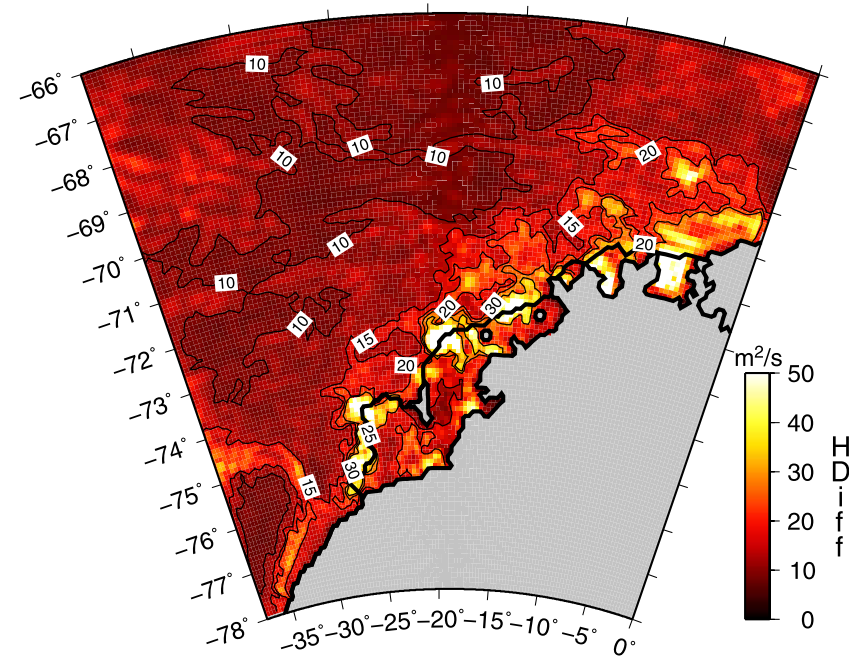

Figure 3. Vertical average of the horizontal Smagorinsky diffusion.

different ice shelf configurations are discussed and results compared with those of the control run. A final discussion and the conclusions are given in section 4 .

\section{Model and Setup}

[8] Ocean circulation is modelled by solving a set of equations based on the nonlinear partial differential NavierStokes equation. The continuity equation ensures mass conservation, while Laplace operators describe the diffusion of the conservative properties salinity and potential temperature. The density is given by an empirical equation of state [Mellor, 1991]. The equations obtained [e.g., Haidvogel and Beckmann, 1999; Griffies, 2004] are simplified by the thin-shell approximation, the hydrostatic assumption, the Boussinesq approximation, incompressibility, the Coriolis approximation, and the Rigid-lid approximation, leading to the so called primitive equations. The corresponding system of equations has been described by Bryan [1969], Cox [1984] and Cox and Bryan [1984] and was transformed to vertically scaled terrain-following $(\sigma-)$ coordinates by Gerdes [1993]. The current ocean model can be traced back to Grosfeld et al. [1997], and has been applied in different regional studies. This model code has been rigorously restructured and improved (e.g., by different diffusion schemes) and is now called ROMBAX (Revisited Ocean Model based on Bryan And Cox). Additionally, we designed a new graphical analysis tool based on open source GMT software [Wessel and Smith, 1998].

[9] Formulations found in various publications, and summarised by Holland and Jenkins [1999], are used to describe the thermodynamic interaction between ocean and ice-shelf base. All formulations are heat and salt conservative, and use an empirical function for the freezing point temperature [Foldvik and Kvinge, 1974]. The amount of melting and freezing in terms of freshwater (salt) fluxes at the ice shelf base influences the density stratification and therefore the thermohaline circulation of the ocean. In our model the vertical plane of the ice shelf front acts as a passive interface, where no melting occurs. The area of this plane exposed to melt processes is small (100 m height times width of grid cell) compared with one lateral grid cell at the ice shelf base (about $10 \mathrm{~km}$ times width of grid cell). Therefore, the amount of melting along the ice shelf front is small (1\%) compared with the impact of the associated grid cell at the ice shelf base, and can be neglected. Bottom friction is parameterised as a drag law in which the stresses are related to the square of the bottom currents through a drag coefficient of $C_{D}=10^{-3}$.

[10] Bathymetry and ice draft for the model domain are taken from the BEDMAP data set [Lythe et al., 2001]. Because these data sets contain inconsistencies, we adjusted the BEDMAP data set beneath the ice shelf in a way that forces a sub-ice shelf water column thickness of at least $3 \mathrm{~m}$ per model layer, by lowering the bedrock where necessary. The horizontal resolution of our model is $0.1^{\circ}(\approx 11 \mathrm{~km})$ in south-north and $0.3^{\circ}(\approx 7-13 \mathrm{~km})$ in west-east direction.

[11] A combination of $z$-layers and depth-scaled $\sigma$-layers is chosen for the vertical grid. The $\sigma$-layer scaling follows Weaver and Sarachik [1990], but is adapted to $15 \sigma$-layers in the open ocean and beneath the ice shelf (each ranging from $2 \%$ to $8 \%$ of the total water column thickness). Four additional $25 \mathrm{~m}$ thick $z$-layers are defined in the open ocean to cover the region between the draft of the ice shelf edge and the surface. Therfore, although the ice edge thickness of EWIS varies between $80 \mathrm{~m}$ and $266 \mathrm{~m}$ in the BEDMAP data set, it is fixed at $100 \mathrm{~m}$ thickness within the model.

[12] We implement a Smagorinsky scheme [e.g., Smagorinsky, 1963; Haidvogel and Beckmann, 1999; Griffies, 2004] with a Karman constant of 0.5 and a background viscosity of $5 \mathrm{~m}^{2} \mathrm{~s}^{-1}$ for the spatially variable eddy viscosity. In the control experiment (model run with general set-up; later called control run to distinguish from scenario studies, where ice shelf configurations are varied) this leads to a time and space averaged viscosity of about $12 \mathrm{~m}^{2} \mathrm{~s}^{-1}$, with sporadic peaks up to about $300 \mathrm{~m}^{2}$ $\mathrm{s}^{-1}$. The largest values for the horizontal viscosity occure in the vicinity of ice shelves and continental margins (Figure 3). For vertical friction a Richardson-Numberdependent scheme is applied, after Pacanowski and Philander [1981]. Timmermann and Beckmann [2004] have shown that this scheme (with a maximum viscosity of $10^{-3} \mathrm{~m}^{2} \mathrm{~s}^{-1}$ and an additional background viscosity of $10^{-4} \mathrm{~m}^{2} \mathrm{~s}^{-1}$ ) gives reasonable results for the parameterisation of vertical mixing in the Weddell Sea. For a better representation of the surface mixed layer, an additional background viscosity of $10^{-3} \mathrm{~m}^{2} \mathrm{~s}^{-1}$ is added to the topmost $z$-layers.

[13] The temporal development of the temperature and salinity distributions in the model is calculated with the implicit diffusion of the flux-corrected transport (FCT) algorithm [Gerdes, 1993]. According to Gerdes [1991] and Thoma et al. [2006], the FCT-scheme has a smaller impact on the solution than an explicit diffusion scheme, based on harmonic (Laplacian) diffusion terms.

[14] The numerical errors introduced into the pressure gradients and the vorticities by the choice of $\sigma$-coordinates are tolerable [Mellor et al., 1993, 1997], and much smaller than errors arising in $z$-level coordinate systems when modelling water mass properties in continental shelf regions [Mellor et al., 2002]. On the other hand, Haney [1991], 


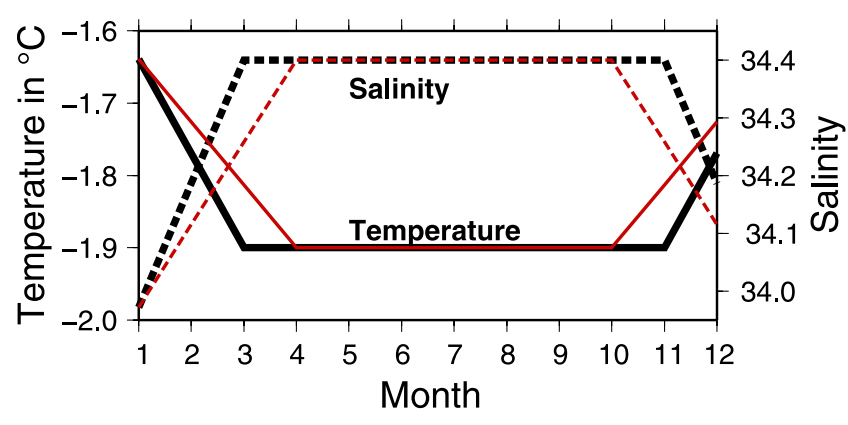

Figure 4. Monthly dependent surface restoring values for an arbitrary grid cell in the open ocean with January values given by Gouretski et al. [1999]. The black line represents the regime for the control run, the red one for a sensitivity study with an elongated summer.

Beckmann and Haidvogel [1993], and Haidvogel and Beckmann [1999], for example, argue that the magnitude of the pressure gradient truncation error depends significantly on the topographic slope, the stratification of the water column, the horizontal and vertical resolution, as well as on the finite difference scheme implemented. All these factors limit the possible topographic slopes that can be adequately resolved, without violating the allowable truncation error. Calculated values for the $r$-value [Beckmann and Haidvogel, 1993], which provide a limitation of the topographic slopes, show more than $96 \%$ of the grid cells below the limit of 0.2 , and less than $2 \%$ above 0.3 . The latter grids cells are partly located along the continental shelf break and in shoals within the ice shelf cavities. More significant is the effect of the steep bathymetry at continental margins on the along- $\sigma$-layer diffusion of momentum and water mass properties. According to Mellor and Blumberg [1985], the diffusion scheme implemented by Gerdes [1993], acting along and perpendicular to $\sigma$-coordinates, is sufficient as long as the upper limit of $\partial H / \partial x$ is about $10 \%$. The maximum topographic gradient is strongly dependent on the horizontal resolution, and reaches up to $17 \%$ in our model domain. We reduce this gradient by applying a spatial filter on the bedrock topography at places where the gradient exceeds a specified limit of 4\% [Thoma et al., 2006]. Spatial filtering of about $4.6 \%$ of the total number of nodes (most of them in the vicinity of the continental margin) with a quadratic filter operator with a span of 24 nodes in the vicinity of each filtered node, reduces the upper limit of the gradient to about $11 \%$. As an additional benefit, smoothing of the bottom topography also leads to a decrease in the pressure gradient error [Ezer and Mellor, 1997; Ly and Jiang, 1999].

[15] The ocean model is initialised with water properties taken from Gouretski et al. [1999] and is forced with:

[16] 1. A climatological monthly wind field after Kottmeier and Sellmann [1996]. The wind stress is calculated by multiplying the square of the observed wind speed by a drag coefficient $C_{D}^{\text {wind }}=1.55 \times 10^{-3}$ and the density $\rho_{\text {air }}=$ $1.3 \mathrm{~kg} \mathrm{~m}^{-3}$.

[17] 2. Restoration of temperature and salinity to initial conditions at the western and northern boundaries of the model domain and to more up-to-date values, published by
Fahrbach et al. [2004], along the eastern boundary. For this a restoring timescale of 1 to 25 days is applied, varying linearly with distance over the last five grid cells: the nudging layer [Marchesiello et al., 2001].

[18] 3. Restoration of temperature and salinity at the ocean surface. In summer, the surface values given by Gouretski et al. [1999] are used, while in winter the temperature is restored to $T=-1.9^{\circ} \mathrm{C}$ throughout, and salinity to $S=34.4$ over the deep ocean. Wintertime salinities over the continental shelf are set to $S=34.5$ to account for increased sea ice production in this area (Figure 4). A restoring timescale of five days is used.

[19] 4. Freshwater fluxes in the EWIS cavities, according to ice-ocean interactions.

[20] 5. Prescribed vertically integrated mass transport values along the open boundaries at the western, northern, and eastern model domain, following the scheme of Stevens [1991].

[21] Open boundary conditions support the development of reasonable flow patterns in regional ocean models [Ezer and Mellor, 2000; Marchesiello et al., 2001]. Along the eastern boundary, where the Antarctic Coastal Current enters the model domain, we apply long term mean values for temperature and salinity measurements from the WOCE A12 transect along the Prime Meridian [Fahrbach et al., 2004]. The prescribed vertically integrated mass transport along the boundaries determines the velocity field along the boundary. Values for the barotropic flow component along the open boundaries are prescribed according to results of large scale simulations for the ocean circulation in the Weddell Sea [Beckmann et al., 1999; Timmermann, 2000; Timmermann et al., 2002a]. The vertically integrated mass transport stream function increases across the coastal current to about $25 \mathrm{~Sv}$ (at the northeastern edge of the model domain), up to a maximum of $35 \mathrm{~Sv}$ in the central Weddell Sea.

\section{Results}

[22] Integration of the model starts with the ocean at rest. A quasi-steady state is reached after about 10 years, and the model is integrated for a total of 30 years.

\subsection{Flow Pattern}

[23] In the control run the dominant feature of the circulation system in the Weddell Sea is the cyclonic (clockwise) Weddell Gyre (Figure 5a) whose structure is closely related both to the predetermined vertically integrated mass transport values prescribed along the open boundaries and to the bathymetry (Figure 2). A mass transport of about $5 \mathrm{~Sv}$ is simulated along the continental slope.

[24] In contrast to many ice shelves (e.g., the FRIS [Grosfeld et al., 2001; Timmermann et al., 2002b]), where a distinct flow regime is established on the continental shelf, the EWIS is in direct contact with the coastal current. The flow system beneath the EWIS (Figure 5b) is characterised by a main through-flow from north to south in a cyclonic sense with several small embedded reverse gyres. The coastal current penetrates underneath the ice shelf in two regions where deep troughs in the bedrock topography appear to enable inflow (see Figure 2). 


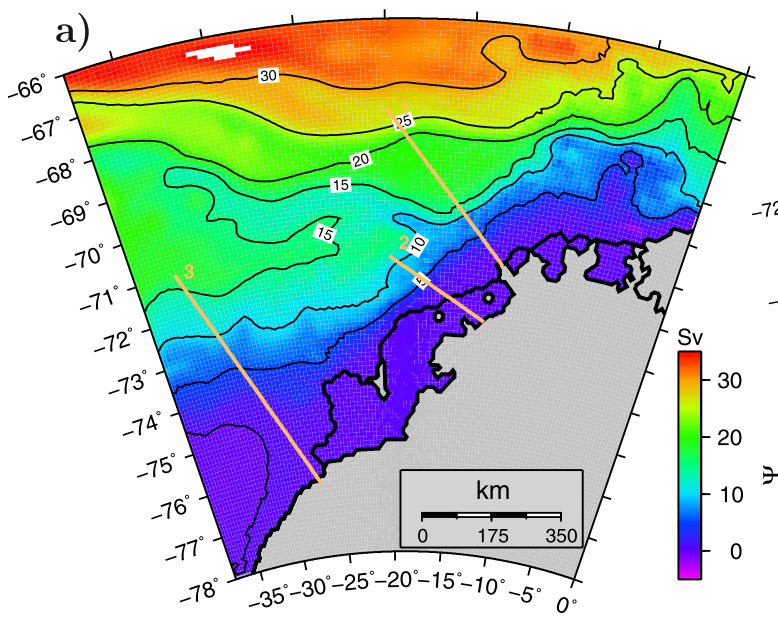

b)

Figure 5. Vertically integrated mass transport (the stream function $\Psi$ ) in (a) the eastern Weddell Sea (complete model domain) and (b) beneath the ice shelf. Brown dots in Figure 5b indicate the position of the ice shelf front in the model grid. Temperature and salinity cross sections along indicated transects are given in Figure 6 (transect 1), Figure 7 (transect 2) and Figures 10, 11 (transect 3).

\subsection{Hydrography}

[25] A model transect perpendicular to Kapp Norwegia and upstream of the EWIS-region (track 1, Figure 2) is shown in Figure 6. Our results generally agree with the observations of Fahrbach et al. [1992, 1994a, 1994b, 2001, 2004]: there is a core of Warm Deep Water (WDW) at about $400 \mathrm{~m}$ depth with temperatures above $0.6^{\circ} \mathrm{C}$ enclosed by colder surface $\left(\lessgtr-1.7^{\circ} \mathrm{C}\right)$ and deep $\left(\lessgtr 0.0^{\circ} \mathrm{C}\right)$ waters. Also in agreement with Fahrbach's observations is the slightly deeper salinity maximum (at about $500 \mathrm{~m}$ depth) and the layer near the surface with salinities below 34.4. The main differences between model and observations are the slightly lower salinity of the modelled WDW core and an overemphasised upwelling of relatively warm and salty water onto the continental shelf. Such an upwelling has not yet been observed in this region. However, Smedsrud et al.
[2006] have modelled a similar feature at the continental shelf break along Fimbulisen with an isopycnal ocean model. Since both models have different model physics this feature might be real, and not an artefact of the model, resulting, for example, from spurious diapycnal mixing, which is often cited as a deficiency in $\sigma$-coordinate models.

[26] Observational data are also available for a second cross section (track 2, Figure 2), perpendicular to the northern Riiser-Larsenisen and about $150 \mathrm{~km}$ downstream of track 1 . However, the tracer properties measured by Fahrbach et al. [1994a] and Heywood et al. [1998] along this track differ significantly from each other: Heywood et al. [1998] describe a WDW core with a temperature above $0.8^{\circ} \mathrm{C}$ and a salinity of up to 34.69 at about $400 \mathrm{~m}$ depth, while the measurements of Fahrbach et al. [1994a] reveal a temperature of $0.5^{\circ} \mathrm{C}$ and a salinity up to 34.68 , a result

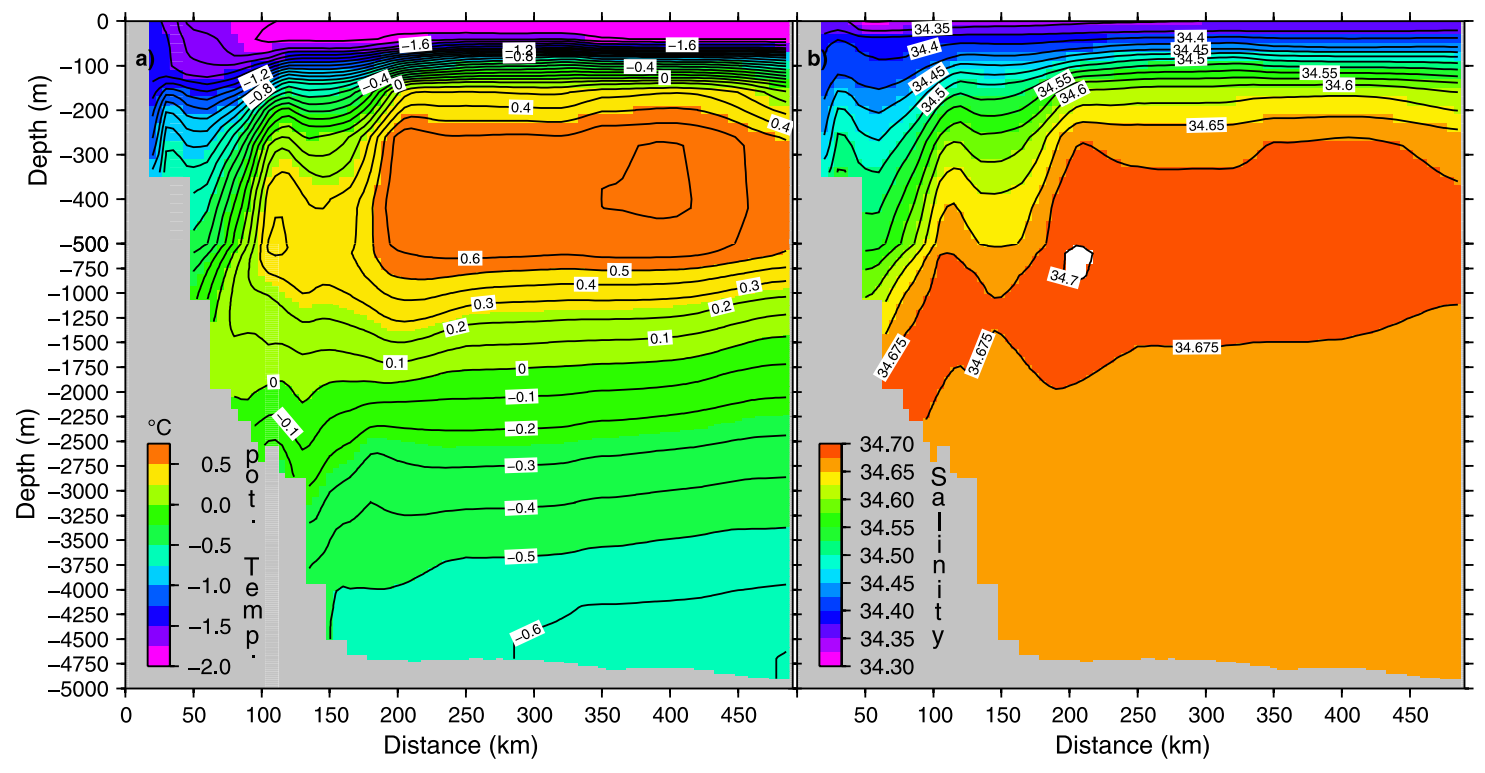

Figure 6. Potential temperature (a) and salinity (b) across the Antarctic Slope Front perpendicular to Kapp Norwegia along track 1 in Figure 2. 


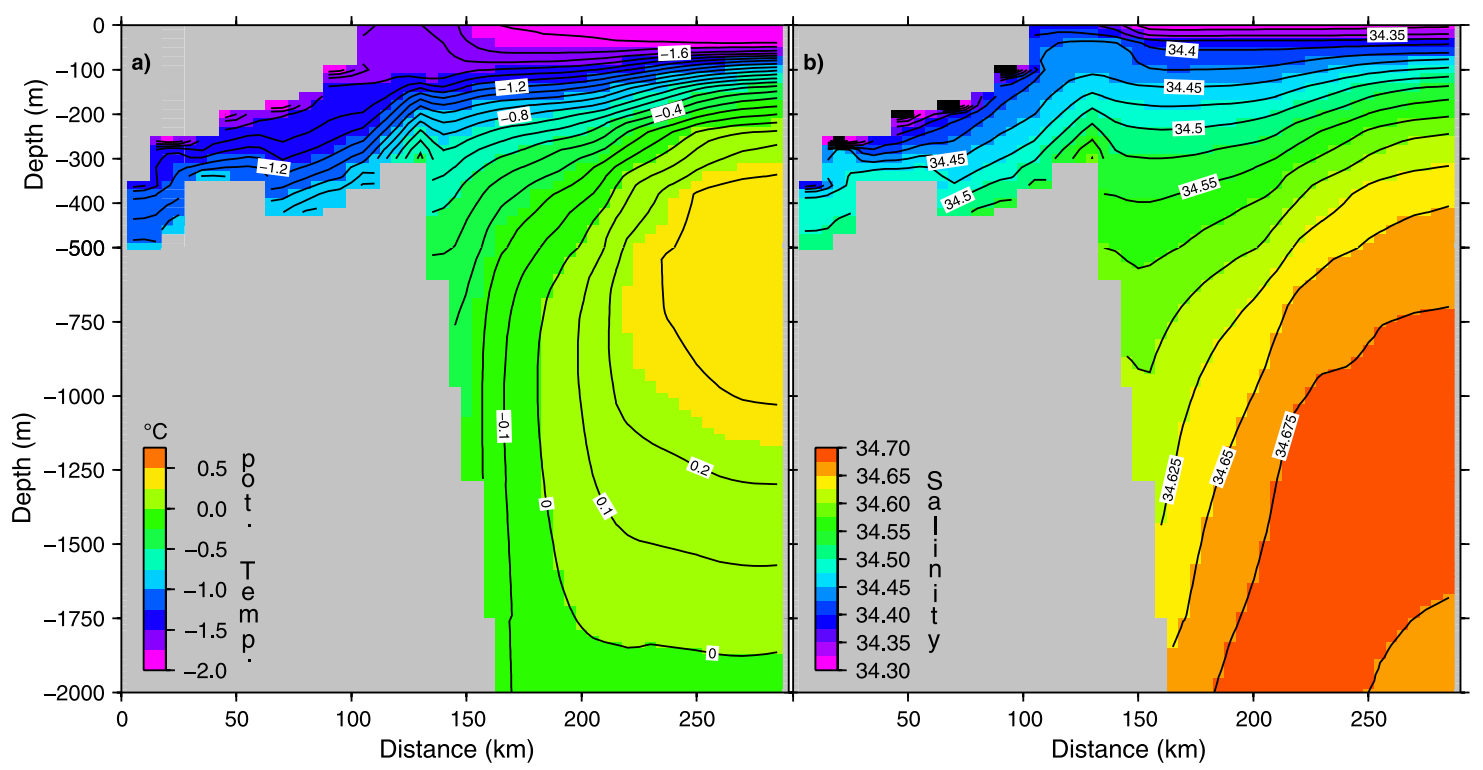

Figure 7. Potential temperature (a) and salinity (b) across the Antarctic Slope Front perpendicular to Riiser-Larsenisen along track 2 of Figure 2.

more consistent with the upstream tracer properties along Kapp Norwegia. Our model results, shown in Figure 7, are closer to the observations of Fahrbach et al. [1994a]. As already seen along track 1 , the main discrepancy of our model results compared with observations is that mixing of cold water from the shelf with warmer waters from the deep ocean is possibly overestimated, preventing the encroachment of unmodified WDW as far as the continental shelf break.

[27] Nevertheless, after 30 years of integration the annual mean water mass properties along this narrow continental shelf appear reasonable, bearing in mind the interannual and seasonal variability as indicated by the differences in two sets of observational snap-shots. During the southern summer the ocean surface temperature increases and the salinity reduces (Figure 4). This leads to fresher water masses on the shelf, countering the effect of the upwelling warmer and saltier water masses originating from the WDW (not shown) and therefore leading to a convergence of observed and modelled conditions in this region. Our model results represent annual mean states, with parameterised climatological sea ice formation. The modelled hydrography for the EWIS region seem therefore to give a realistic representation of the eastern Weddell Sea system and can be utilised to investigate the impact of the ice shelf on water mass formation.

\subsection{Freshwater Production}

[28] The distribution of melting and freezing in the EWIS region is shown in Figure 8. The highest melt rates are found near the ice shelf front, in the northern part of the Riiser-Larsenisen, and near the grounding line where the Stancomb-Wills and Veststraumen Ice Streams enter the ice shelf. The latter regions are associated with relatively large ice thicknesses. Moderate freezing takes place between the grounding line and the ice shelf front, and downstream of the Stancomb-Wills Ice Stream grounding line. Table 1 compares values for the basal mass balance in the EWIS region derived from different model studies and observations.
[29] Based upon glaciological field measurements along individual ice flow lines, Thomas [1973] and Gjessing and Wold [1986] calculated melt rates of $1.3-3.3 \mathrm{~m} \mathrm{yr}^{-1}$ for Brunt Ice Shelf and 1.5-2.3 m yr ${ }^{-1}$ for Riiser-Larsenisen, respectively. Fahrbach et al. [1994a] deduced $\approx 2.3 \mathrm{~m} \mathrm{yr}^{-1}$ as an upper limit for the melt rate, based upon calculations of the on-shelf heat transport, derived from CTD (Conductivity, Temperature, Depth) measurements. The freshwater flux modelled by Beckmann and Goosse [2003] using the BRIOS model for two different atmospheric forcing data sets was $3.95 \mathrm{mSv}$ and $4.4 \mathrm{mSv}$, respectively. Based on a simple parameterisation of the impact of probable basal melting beneath ice shelves in global climate models, and using a characteristic length scale for the heat exchange between the ice shelf base and the ocean, and a temperature difference between freezing temperature at the ice base and an oceanic temperature on the shelf/slope area of the adjacent ocean, basal melting for the EWIS region varies between $1.02 \mathrm{mSv}$ and $1.87 \mathrm{mSv}$, depending on the cross-

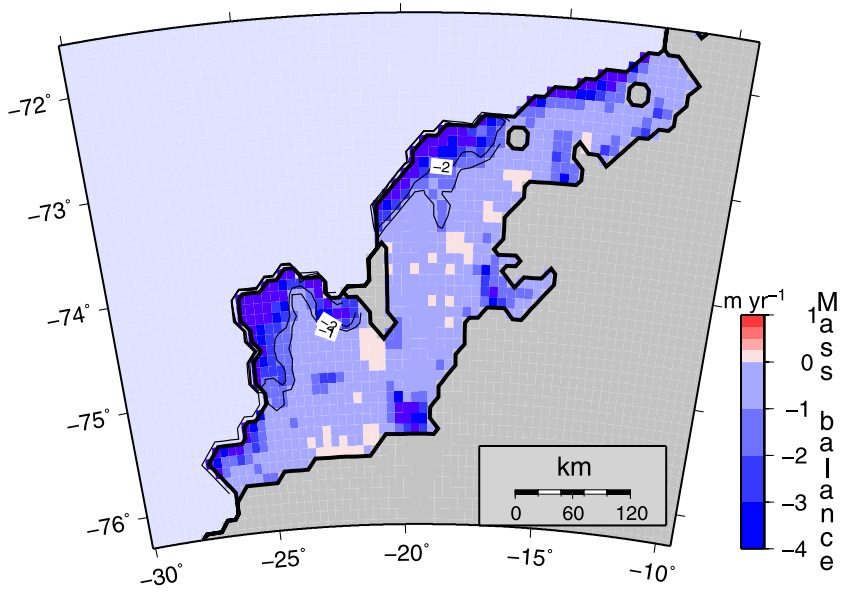

Figure 8. Melting (negative) and freezing (positive) in the EWIS region. 
Table 1. Different Melt and Freshwater Production Rates Based Upon Field Measurements $(f)$ and Numerical Models $(m)$ for the EWIS Region $^{\text {a }}$

\begin{tabular}{llcc}
\hline \multicolumn{1}{c}{ Author } & & Basal Mass Balance, $\mathrm{km}^{3} \mathrm{yr}^{-1}$ & Freshwater Production, $\mathrm{mSv}$ \\
\hline Thomas [1973] & $f$ & & $\mathrm{Mean} \mathrm{Melt} \mathrm{Rate,} \mathrm{m}$ yr $^{-1}$ \\
Gjessing and Wold [1986] & $f$ & & $1.3-3.3$ \\
Fahrbach et al. [1994a] & $f$ & & $1.5-2.3$ \\
Beckmann and Goosse [2003] (param.) & $m$ & & $1.02-1.87$ \\
$\quad$ (NCEP, ECMWF forcing) & $m$ & & $3.95,4.40$ \\
Timmermann and Beckmann [2004] & $m$ & 181 & 4.20 \\
Hellmer [2004] & $m$ & 66.4 & 5.19 \\
This study (annual mean) & $m$ & $52-102$ & 2.10 \\
$\quad$ (seasonal variability) & & $64-80$ & $1.66-3.24$ \\
$\quad$ (mod. bound. cond.) & & 0.88 \\
\hline
\end{tabular}

${ }^{\text {a }}$ The two last rows show variabilities of seasonal fluctuations of the control experiment and annual mean results for modified boundary conditions.

shelf length. Timmermann and Beckmann [2004] calculated a freshwater flux of $4.2 \mathrm{mSv}$ for the EWIS, using a bulk formulation for the ice-ocean interaction and a coarser resolution ocean model than that used in our study. Hellmer [2004] calculated $5.19 \mathrm{mSv}$ but assesses his high value as an overestimate because of an insufficiently resolved narrow continental shelf, leading to a stronger interaction between the coastal current and the ice shelf cavity. As mentioned above, this problem has also been investigated by Nicolaus and Grosfeld [2002] who found a significant dependence between shelf width and calculated basal melt rate for Ekströmisen.

[30] Since the annual mean of the basal mass balance is quite stable after about ten years (Figure 9a), the climatological annual mean for the control run of this study is calculated from year 11 to year 30 of the integration.

[31] Figure 9b shows that there is strong seasonal variability of about $100 \%$ driven by the surface temperature conditions. To investigate the sensitivity of the basal mass balance to different aspects of the model forcing we performed experiments where we (1) slightly increase the inflow of cold and fresh shelf water masses along the Prime Meridian by altering the prescribed stream function (this results in a $3 \%$ decrease in the annual mean basal melt rate), (2) use a constant wintertime surface restoring salinity (34.4) over the entire domain, both continental shelf and deep ocean (this results in a 10\% increase in the annual mean basal melt rate and is consistent with results of Smedsrud et al. [2006]), and (3) extend the southern summer from three to five months (Figure 4, this results in a $20 \%$ increase in the annual mean basal melt rate).

[32] Combining the impact of the seasonal fluctuation and the modified boundary conditions, we derive a seasonally dependent freshwater production rate of $1.60-3.91 \mathrm{mSv}$ (equivalent to $48-123 \mathrm{~km}^{3} \mathrm{yr}^{-1}$ or $0.67-1.65 \mathrm{~m} \mathrm{yr}^{-1}$ ). The freshwater formation rate also depends on the mathematical formulation of the ice-ocean interaction [Thoma et al., 2005]. A simpler bulk formulation results in an increase in basal melting of about 34\% [Thoma et al., 2005]. In summary, our results are in good agreement with previous field studies. The modelled meltrates are lower than from other model studies, probably a result of the high model resolution and the more sophisticated parametrization of the ice-shelf ocean fluxes employed in this study.

\subsection{Scenario Studies}

[33] In the following, we analyse the impact of the EWIS freshwater input on the ocean circulation and the water masses in the south-eastern Weddell Sea. We consider three different scenarios and investigate their influence on the circulation in terms of the vertically integrated mass transport, temperature, salinity, and density in the outflow region. Although the chosen scenarios are artificial and the changes only apply to the ice shelf configuration, the input of the glacial freshwater flux and the changed ice shelf coverage of the narrow continental shelf on the eastern Weddell Sea flow regime can be studied. The temperature, salinity and density along track 3 (Figures 2 and 10) for the control run are given in Figure 10. The cross section through the Helmert Bank and the adjacent continental rise shows the water mass properties after the coastal current has passed south-westward along the EWIS. Because the vertically integrated mass transport in this shelf region is very weak (Figure 5b), the surface restoring leads to an accumulation of cold (temperatures below about $-1.5^{\circ} \mathrm{C}$ ) and salty (salinity about 34.5 )
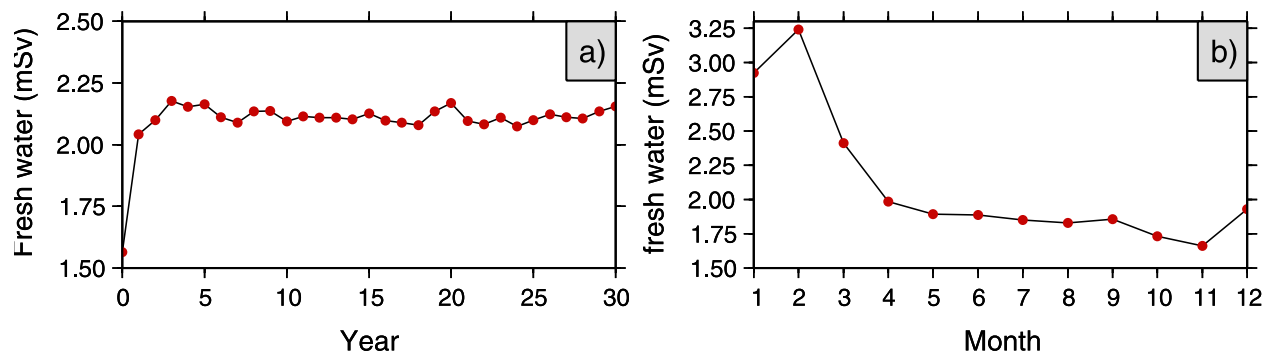

Figure 9. (a) Freshwater production after starting the model from scratch. Averaged values for years $10-30$ are: $66.4 \mathrm{~km}^{3} \mathrm{yr}^{-1}$ (equivalent to $2.10 \mathrm{mSv}$ or $0.88 \mathrm{~m} \mathrm{yr}^{-1}$. (b) Monthly average values for years $10-30$. 

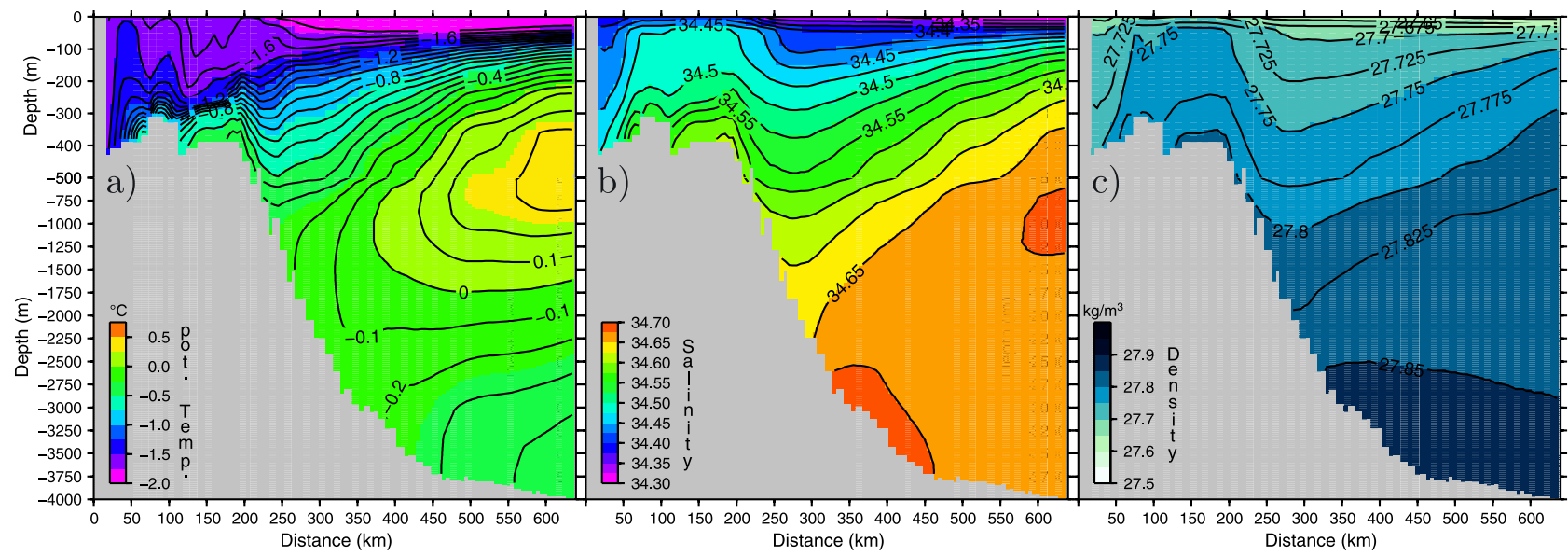

Figure 10. (a) Potential temperature, (b) salinity and (c) density along track 3 in Figure 2.

waters. The WDW core with temperatures above $0.0^{\circ} \mathrm{C}$ reaches to within about $200 \mathrm{~km}$ of the shelf.

[34] In the first scenario we keep the geometry of the model configuration the same but suppress the ice-ocean interaction by setting the freshwater formation rate at the ice-shelf base to zero. This experiment is designed to give an estimate of the effect of glacial freshwater input of the EWIS. In the other scenarios we alter the geometry of the model configuration by removing the EWIS (scenario two) and by closing the ice shelf cavity (scenario three). With these model experiments two extreme conditions are simulated: a glacial analog with glaciers extending to the continental shelf break, and a climate warming analog, in which the ice shelves have disintegrated. Other boundary conditions, such as the inflow in the north-east and the surface forcing are kept the same as for the control run in order to focus only on the freshwater impact of the changed glacial system. Differences between the control run and the scenarios 1-3 are shown in Figure 11.

[35] In the first scenario, where ice shelf - ocean interaction is suppressed at the ice shelf base, no latent heat is extracted from the ocean within the ice shelf cavity (Figure $11 \mathrm{~b})$. This results in warmer waters $\left(\approx 0.5^{\circ} \mathrm{C}\right)$ relative to the control run, in which cold waters enriched with ISW leave the ice shelf cavity. In addition a wide area of slightly warmed $\left(\approx 0.1-0.3^{\circ} \mathrm{C}\right)$ water is found at about 100-200 $\mathrm{m}$ depth over the continental rise. This water mass left the ice shelf cavity further upstream and mixed with surrounding water masses while flowing downstream. The extensively increased salinity (most obvious near the coast, Figure 11c) is also a result of the absence of the addition of freshwater in this scenario. Consequently, the density (Figure 11d) of the water masses are slightly increased. The modified hydrography results in a small decrease in the vertically integrated mass transport (Figure 11a) in front of the Riiser-Larsenisen and a small increase in front of the Brunt Ice Shelf. Both changes originate where the ice shelf advances over the continental shelf break. The spatial variability of the vertically integrated mass transport near the western model boundary derive from modified water masses interacting with the boundary conditions.
[36] If the ice shelf is removed (second scenario), the larger area of open ocean over the continental shelf leads to higher salinity and lower water temperatures, compared with both the control run and scenario one. This scenario can be viewed as a more extreme case of the first scenario, where only the effect of ice ocean interaction was switched off, but with unchanged geometry. The effect of the increased surface salinity forcing over the open continental shelf is quite obvious (Figure $11 \mathrm{~g}$ ). Salinity is increased over the shelf, but also in the coastal current to depths of $1000 \mathrm{~m}$, up to $200 \mathrm{~km}$ off-shore in the deep sea. The same holds for temperature, which shows $\approx 0.7^{\circ} \mathrm{C}$ warming in the deep layers over the continental shelf (Figure 11f). Cooling of the upper layers is a result of the imposed winter convection in this area. The net effect is for the density (Figure 11h) of the coastal current to be increased throughout the water column, when compared with the control run. In the first scenario the effect of the missing ISW was to decrease the mass transport in front of the ice shelf edge. In scenario two the loss of the ice shelf results in an increased ocean volume, and the additional forcing due to the surface restoring over a larger ocean area. This results in an increased mass transport in the vicinity and downstream of the absent ice shelf, so that the coastal current is more intense and lies closer to the continental shelf break (Figure 11e).

[37] In scenario three, where the ice shelf cavity is closed, the flow system reacts in an opposite manner to the other scenarios. The coastal current is largely reduced in the southern part of the EWIS region (Figure 11i). As the southward transport of relatively warm water by the coastal current is decreased, the temperatures on the continental shelf are significantly colder $\left(\approx 0.1-0.7^{\circ} \mathrm{C}\right)$ compared with those in the control run (Figure 11j). Salinity (Figure 11k), and therefore density (Figure 111), is increased in the upper layers and decreased in the lower layers of the ocean in general, leading to a destabilisation of the water column.

\section{Discussion and Conclusion}

[38] Employing the refined terrain-following numerical ocean model ROMBAX, which resulted from earlier workes of Gerdes [1993], Determann and Gerdes [1994] and 

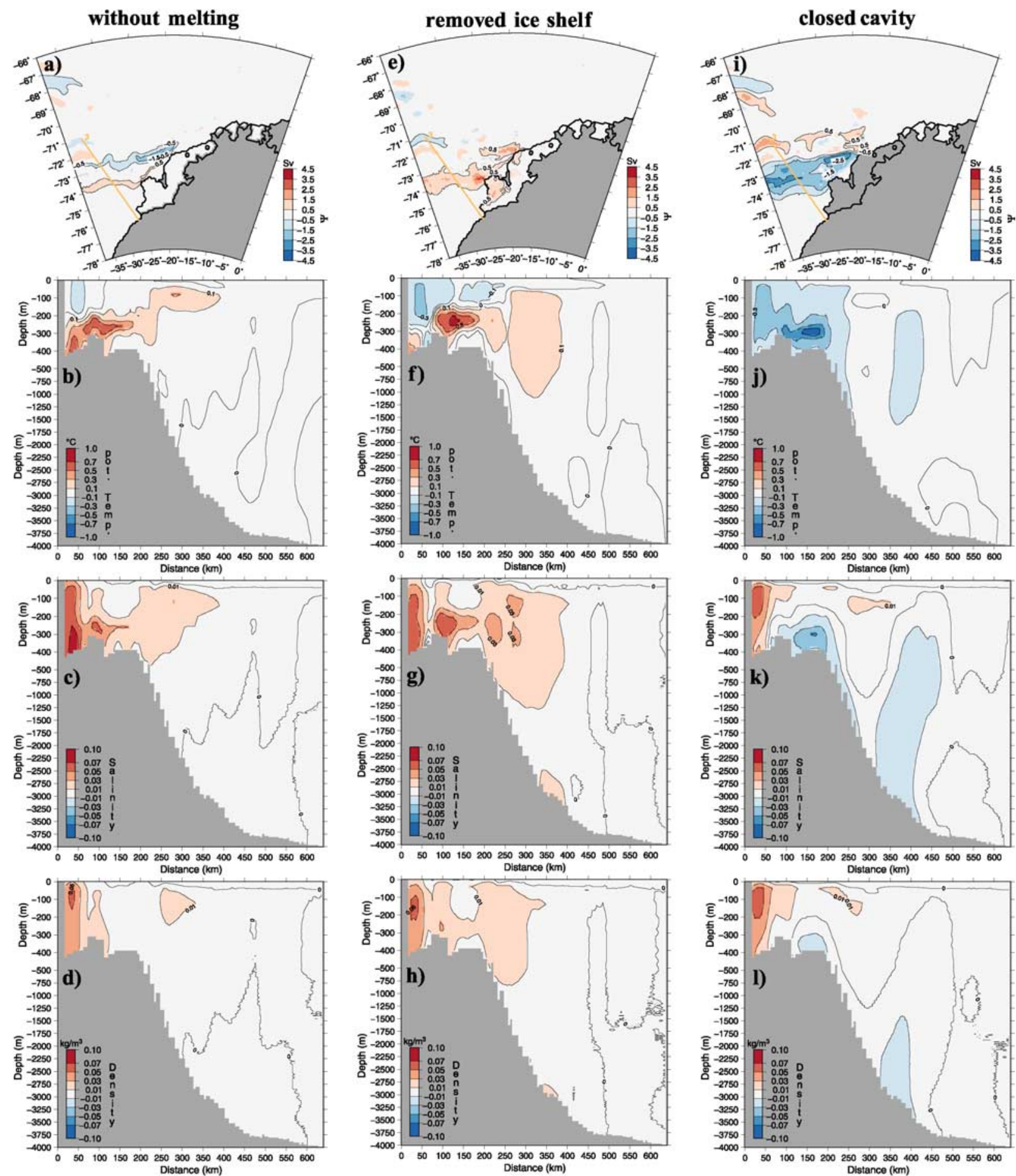

Figure 11. Differences of (from top to bottom) the vertically integrated mass transport stream function, the potential temperature, the salinity and the density after the Coastal Current has passed EWIS from north to south (track 3) for different ice shelf configurations.

Grosfeld et al. [1997], we simulate the ocean circulation and ice shelf - ocean interaction in the Eastern Weddell Sea. From comparisons with observed temperature and salinity data [Fahrbach et al., 1992, 1994b, 1994a, 2001, 2004; Heywood et al., 1998] we conclude that our model simu- lates with reasonable accuracy the mean hydrographic state in this region. Although the model tends to overestimate upwelling of warmer water from deep layers, this apparently has no serious consequences for the modelled basal mass balance, which compares favourably with observations. At 
the same time, downwelling of colder water masses prevents the WDW core extending close to the continental slope. Nevertheless, differences between observations made in different years and seasons indicate a strong variability of the flow system in the eastern Weddell Sea [Fahrbach et al., 1992]. As the model is driven with climatological forcing, it is not expected to simulate specific observed conditions.

[39] We have shown that the seasonal variations of the basal mass balance are substantial, with summer melting twice as high as that during winter. Applying different boundary conditions for our ocean model forcing (surface salinity, length of summer season, strength of inflow at the Prime Meridian), we derive a basal mass balance (freshwater production) of about $0.67-1.65 \mathrm{~m} \mathrm{yr}^{-1}$ (1.60-3.91 mSv), which is in good agreement with earlier estimates from field observations.

[40] We have explored the impact of EWIS on the water masses of the south-eastern Weddell Sea with three experimental scenarios in which the interaction between ice shelf and ocean is absent: no melting or freezing, no ice shelf, and closed ice shelf cavity. The modelled temperatures downstream of the EWIS differed by up to $\pm 0.7^{\circ} \mathrm{C}$ from the control run and the salinity was increased by as much as 0.05 . Thus the absence of the freshwater input from the EWIS induces a destabilisation of the water column that has consequences for the vertical heat exchange and hence the sea ice cover. Our results are in agreement with Hellmer [2004] who studied a scenario with closed ice shelf cavities in a coarser resolution model covering the entire Southern Ocean. Hellmer [2004] found that the continental shelf waters generally become warmer and saltier when the freshwater from the ice shelf caverns was absent, but that cooling and salt enrichment also took place where closure of the ice shelf caverns reduced the southward flow of warmer waters onto the shelves [Assmann et al., 2003]. In Hellmer's [2004] circumpolar model the latter result was only observed in the Ross Sea. In our finer-resolution regional model, closure of the ice shelf caverns (scenario three) reduces the southward flow of warm waters onto the continental shelf of the south-eastern Weddell Sea, and thus leads to colder and saltier conditions on the shelf than found in the control run. In contrast, suppression of melting and freezing at the ice shelf base (scenario one) and in complete removal of the ice shelf (scenario two) both lead to warming and salt enrichment compared with the control run, because the southward flow of warm water is unimpeded. All three scenarios show that the present ice shelf configuration contributes to the stabilisation of the water column in the southeastern Weddell Sea and therefore to the suppression of deep and bottom water formation, as mentioned by Fahrbach et al. [1994a].

[41] Considering the importance of water mass formation in the EWIS region for the FRIS, located downstream along the coastal current from the EWIS, we conclude that any kind of change in the EWIS region will have repercussions for the FRIS. In particular, extreme scenarios of a completely disintegration of the EWIS on the one hand, or complete grounding of the EWIS, would have significant consequences for the preconditioning of waters entering the FRIS region. Indeed, additional model studies (not shown), covering the whole Weddell Sea area, suggest an increase of basal melting in the FRIS region of about $7 \%$ in the case of an absent EWIS. This, in turn, would influence the mass balance of the FRIS and thus the production of bottom water in the southwestern Weddell Sea.

[42] Acknowledgments. This work is part of the German CLIVAR/ marin-project. Funding by the Bundesministerium für Bildung, Wissenschaft, Forschung und Technologie $(b m b+f)$ der Bundesrepublik Deutschland, contract $03 \mathrm{~F} 0377 \mathrm{C}$, is gratefully acknowledged. The authors are grateful to Rüdiger Gerdes for providing the numerical FCT-code in $\sigma$-coordinates, to Stan Jacobs for his comments on an earlier version of this manuscript, and to Adrian Jenkins and Keith Nicholls for their support during the final phase. Comments and suggestions from three anonymous reviewers helped to improve the manuscript.

\section{References}

Assmann, K., H. H. Hellmer, and A. Beckmann (2003), Seasonal variation in circulation and water mass distribution on the Ross Sea continental shelf, Anatarct. Sci., 15, 3-11.

Baines, P. G., and S. Condie (1998), Observations and modelling of Antarctic downslope flows: A review, in Ocean, Ice, and Atmosphere: Interactions at the Antarctic Continental Margin, Antarct. Res. Ser, vol. 75, edited by S. S. Jacobs and R. Weiss, pp. 29-49, AGU, Washington, D. C.

Beckmann, A., and H. Goosse (2003), A parametrization of ice shelf ocen interaction for climate models, Ocean Modell., 5, 157-170.

Beckmann, A., and D. B. Haidvogel (1993), Numerical simulation of flow around a tall isolated seamount. part i: problem formulation and model accuracy, J. Phys. Oceanogr., 23, 1736-1753.

Beckmann, A., H. H. Hellmer, and R. Timmermann (1999), A numerical model of the Weddell Sea: Large scale circulation and water mass distribution, J. Geophys. Res., 104, 23,375-23,391.

Bryan, K. (1969), A numerical method for the study of the circulation of the world ocean, J. Comp. Phys., 4, 347-376.

Cox, M. D. (1984), A primitive equation, 3-dimensional model of the ocean, Tech. Rep. GFDL Ocean Group Tech. Rep. 1, Princeton Univ., Princeton, N. J.

Cox, M. D., and K. Bryan (1984), A numerical model of the ventilated thermocline, J. Phys. Oceanogr., 14.

Determann, J., and R. Gerdes (1994), Melting and freezing beneath ice shelves: Implications from a 3-d ocean circulation model, Ann. Glaciol., $20,413-419$.

Ezer, T., and G. L. Mellor (1997), Simulations of the Atlantic Ocean with a free surface sigma coordinate ocean model, J. Geophys. Res., 102, $15,647-15,657$.

Ezer, T., and G. L. Mellor (2000), Sensitivity studies with the North Atlantic sigma coordinate Princeton Ocean Model, Dyn. Atmos. Oceans, 32, 185-208.

Fahrbach, E., G. Rohardt, and G. Krause (1992), The Antarctic Coastal Current in the southeastern Weddell Sea, Polar Biol., 12, 171-182.

Fahrbach, E., R. G. Peterson, G. Rohardt, P. Schlosser, and R. Bayer (1994a), Suppression of bottom water formation in the southeastern Weddell Sea, Deep Sea Res., 41, 389-411.

Fahrbach, E., G. Rohardt, M. Schröder, and V. Strass (1994b), Transport and structure of the Weddell Sea, Ann. Geophys., 12, 840-855.

Fahrbach, E., S. Harms, G. Rohardt, M. Schröder, and R. A. Woodgate (2001), Flow of bottom water in the northwestern Weddell Sea, J. Geophys. Res., 106, 2761-2778.

Fahrbach, E., M. Hoppema, G. Rohardt, M. Schröder, and A. Wisotzki (2004), Decadal-scale variations of water mass properties in the deep Weddell Sea, Ocean Dyn., 54, 77-91.

Foldvik, A., and T. Gammelsrød (1988), Notes on southern ocean hydrography, sea ice and bottom water formation, Palaeogeogr., Palaeocl. $67,3-17$

Foldvik, A., and T. Kvinge (1974), Conditional instability of sea water at the freezing point, Deep Sea Res., 21, 169-197.

Foldvik, A., T. Gammelsrød, N. Slotsvik, and T. Tørresen (1985), Circulation and water masses on the southern Weddell Sea shelf, in Oceanology of the Antarctic Continental Shelf, Antarct. Res. Ser., vol. 43, edited by S. S. Jacobs, pp. 5-20, AGU, Washington, D. C.

Fox, A. J., and A. P. R. Cooper (1994), Measured properties of the Antarctic ice sheet derived from the SCAR Antarctic digital database, Polar Records, 30, 201-206.

Gerdes, R. (1991), The influence of numerical advection schemes on the result of ocean general circulation models, Clim. Dyn., 5, 211-226.

Gerdes, R. (1993), A primitive equation ocean circulation model using a general vertical transformation: 1. Description and testing of the model, J. Geophys. Res., 98, 14,683-14,701. 
Gjessing, Y., and B. Wold (1986), Absolut movements, mass balance and snow temperatures of the Riiser-Larsenisen, Antarctica, Norsk Polarinstitutt, Skrifter, 187, 23-31.

Gouretski, V., K. Jancke, J. Reid, J. Swift, P. Rhines, R. Schlitzer, and I. Yashayaev (1999), WOCE Hydrographic Programme Special Analysis Centre, Atlas of Ocean Sections [CD-ROM]

Griffies, S. M. (2004), Fundamentals of Ocean Climate Models, Princeton Univ. Press, Princeton, N. J.

Grosfeld, K., and R. Gerdes (1998), Circulation beneath the Filchner Ice Shelf and its sensitivity to changes in the oceanic environment: a case study, Ann. Glaciol., 27, 99-104.

Grosfeld, K., R. Gerdes, and J. Determann (1997), Thermohaline circulation and interaction beneath ice shelf cavities and the adjacent open ocean, J. Geophys. Res., 102, 15,595-15,610.

Grosfeld, K., M. Schröder, E. Fahrbach, R. Gerdes, and A. Mackensen (2001), How iceberg calving and grounding change the circulation and hydrography in the Filchner Ice Shelf - ocean system, J. Geophys. Res. 106, 9039-9055.

Haidvogel, D. B., and A. Beckmann (1999), Numerical Ocean Circulation Modeling, Imperial Coll. Press, London.

Haney, R. L. (1991), On the pressure gradient force over steep topography in sigma coordinate ocean models, J. Phys. Oceanogr., 21, 610-619.

Hellmer, H. H. (2004), Impact of Antarctic ice shelf basal melting on sea ice and deep ocean properties, Geophys. Res. Lett., 31, L10307, doi:10.1029/ 2004GL019506.

Heywood, K. J., R. A. Locarnini, R. D. Frew, P. F. Dennis, and B. A. King (1998), Transport and water masses of the Antarctic slope front system in the eastern Weddell Sea, in Ocean, Ice, and Atmosphere: Interactions at the Antarctic Continental Margin, Antarct. Res. Ser., vol. 75, edited by S. S. Jacobs and R. F. Weiss, pp. 203-214, AGU, Washington, D. C.

Holland, D. M., and A. Jenkins (1999), Modeling thermodynamic ice-ocean interaction at the base of an ice shelf, J. Phys. Oceanogr., 29, $1787-$ 1800 .

Jenkins, A., and D. M. Holland (2002), A model study of ocean circulation beneath Filchner-Ronne Ice Shelf, Antarctica: Implications for bottom water formation, Geophys. Res. Lett., 29(8), 1193, doi:10.1029/ 2001 GL014589.

Kottmeier, C., and L. Sellmann (1996), Atmospheric and oceanic forcing of Weddell Sea ice motion, J. Geophys. Res., 101, 20,809-20,824

Ly, L. N., and L. Jiang (1999), Horizontal pressure gradient errors of the Monterey Bay sigma coordinate ocean model with various grids, J. Oceanogr., 55, 87-97.

Lythe, M. B., et al. (2001), BEDMAP: A new ice thickness and subglacial topographic model of the Antarctic, J. Geophys. Res., 106, 11,33511,351 .

Marchesiello, P., J. C. McWilliams, and A. Shchepetkin (2001), Open boundary conditions for long-term integration of regional oceanic models, Ocean Modell., 3, 1-20.

Mellor, G. L. (1991), An equation of state for numerical models of oceans and estuaries, J. Atmos. Oceanic Technol., 8, 609-611.

Mellor, G. L., and A. F. Blumberg (1985), Modeling vertical and horizontal diffusivities with the sigma coordinate system, Mon. Weather Rev., 113, $1379-1383$.

Mellor, G. L., T. Ezer, and L.-Y. Oey (1993), The pressure gradient conundrum of sigma coordinate ocean models, J. Atmos. Oceanic Technol., $11,1126-1134$
Mellor, G. L., L.-Y. Oey, and T. Ezer (1997), Sigma coordinate pressure gradient errors and the seamount problem, J. Atmos. Oceanic Technol., $15,1122-1131$

Mellor, G. L., S. Häkkinen, T. Ezer, and R. Patchen (2002), A generalization of a sigma coordinate ocean model and an intercomparison of model vertical grids, in Ocean Forecasting: Conceptual Basis and Applications, edited by N. Pinardi and J. Woods, pp. 55-72, Springer, New York.

Nicolaus, M., and K. Grosfeld (2002), Ice - ocean interaction underneath the Antarctic ice shelf Ekströmisen, Polarforschung, 72, 17-29.

Pacanowski, R. C., and S. G. H. Philander (1981), Parameterization of vertical mixing in numerical models of the tropical oceans, J. Phys. Oceanogr., 11, 1443-1451.

Smagorinsky, J. (1963), General circulation experiments with the primitive equations: I. the basic experiment, Mon. Weather Rev., 91, 99-164.

Smedsrud, L. H., A. Jenkins, D. M. Holland, and O. A. Nøst (2006), Modeling ocean processes below Fimbulisen, Antarctica, J. Geophys. Res., 111, C01007, doi:10.1029/2005JC002915.

Stevens, D. P. (1991), The open boundary condition in the United Kingdom Fine-Resolution Antarctic Model, J. Phys. Oceanogr., 21, 1494-1499.

Thoma, M., K. Grosfeld, C.-O. Mohrholz, and M. A. Lange (2005), Modelling ocean circulation and ice - ocean interaction in the southeastern Weddell Sea, FRISP Rep., 16, 33-42.

Thoma, M., K. Grosfeld, and M. A. Lange (2006), The impact of mixing parameterisation and bathymetry filtering on the simulated hydrography along steep continental shelf regions in terrain following ocean models, FRISP Rep., 17.

Thomas, R. H. (1973), The dynamics of the Brunt Ice Shelf, Coats Land, Antarctica, Sci. Rep. 79, Br. Antarct. Surv., Cambridge, UK.

Timmermann, R. (2000), Wechselwirkungen zwischen Eis und Ozean im Weddellmeer, Ph.D. thesis, Univ. Bremen, Bremen, Germany.

Timmermann, R., and A. Beckmann (2004), Parameterization of vertical mixing in the Weddell Sea, Ocean Modell., 6, 83-100, doi:10.1016 S1463-5003(02)0061-6.

Timmermann, R., A. Beckmann, and H. H. Hellmer (2002a), Simulation of ice-ocean dynamics in the Weddell Sea: 1. Model configuration and validation, J. Geophys. Res., 107(C3), 3024, doi:10.1029/2000JC000741.

Timmermann, R., H. H. Hellmer, and A. Beckmann (2002b), Simulation of ice-ocean dynamics in the Weddell Sea: 2 . Interannual variability $1985-$ 1993, J. Geophys. Res., 107(C3), 3025, doi:10.1029/2000JC000742.

Weaver, A. J., and E. S. Sarachik (1990), On the importance of vertical resolution in certain ocean general circulation models, J. Phys. Oceanogr., 20, 600-609.

Weiss, R. F., H. G. Oestlund, and H. Craig (1979), Geochemical studies of the Weddell Sea, Deep Sea Res., 26, 1093-1120.

Wessel, P., and W. H. F. Smith (1998), New, improved version of Generic Mapping Tools released, Eos Trans. $A G U, 79,579$.

K. Grosfeld, Alfred Wegener Institute for Polar and Marine Research, D-27515 Bremerhaven, Germany.

M. A. Lange, Institute for Geophysics, University of Münster, Corrensstraße 24, D-48149 Münster, Germany.

M. Thoma, British Antarctic Survey, Cambridge CB3 0ET, UK. (thoma@uni-muenster.de) 